\title{
MANAJEMEN PROGRAM PERENCANAAN, PELAKSANAAN, DAN EVALUASI MUNADHARAH 'ILMIYAH PEKAN ARABI DI UNIVERSITAS NEGERI MALANG DI MASA PANDEMI
}

\author{
Muhammad Nahidh Islami' ${ }^{1}$ Dalilan Aini' ${ }^{2}$, Eva Famila Rosyida ${ }^{3}$, \\ Zakiyah Arifa ${ }^{4}$, Umi Machmudah ${ }^{5}$ \\ 1 UIN Maulana Malik Ibrahim Malang \\ 2UIN Maulana Malik Ibrahim Malang \\ 3UIN Maulana Malik Ibrahim Malang \\ ${ }^{4}$ UIN Maulana Malik Ibrahim Malang \\ 5UIN Maulana Malik Ibrahim Malang \\ Email: hidhislami@gmail.com
}

\begin{abstract}
This The purpose of this study is to describe the management planning, implementation, and evaluation of the munadharah ilmiyah program Pekan Arabi at the State University of Malang during the pandemic. This type of research in research is a type of qualitative research with descriptive methods. Data collection techniques are using interview and documentation methods. Data analysis techniques, the researchers used Miles and Huberman's theory, namely collecting data from interviews and documentation, data reduction, data display, and conclusion drawing. The results of the research and the discussion of this research are 1. Planning, three important things must be fulfilled in planning the munadharah 'ilmiyah program. First, the interactive approach model. Second, within the scope of this program, there are three dimensions. Third, the program planning process goes through systematic stages. 2. Implementation, there are three substantial things are found in the preparation of the Munadharah 'ilmiyah program. First, the beginner level, Second, the program implementation stage, Third, the evaluation stage after the munadharah 'ilmiyah program. 3) Evaluation two significant things must be fulfilled in the evaluation of the munadharah 'ilmiyah program, namely the evaluation of comprehensive monitoring and evaluation.
\end{abstract}

Keywords: Evaluation, Implementation, Munadharah 'ilmiyah, Planning, Program Management.

\begin{abstract}
Abstrak
Tujuan dari penelitian ini adalah mendeskripsikan manajemen perencanaan, pelaksanaan dan evaluasi program munadharah 'ilmiyah Pekan Arabi di Universitas Negeri Malang di masa pandemi. Jenis penelitian dalam penelitian ialah jenis penelitian kualitatif metode deskriptif. Teknik pengumpulan data yaitu menggunakan metode wawancara dan dokumentasi. Teknik analisis data, peneliti menggunakan teori Miles dan Huberman, yaitu mengumpulkan data dari hasil wawancara dan dokumentasi, reduksi data, display data, dan conclusion Drawing. Hasil penelitian dan pembahasan penelitian ini terdiri dari 1) Perencanaan, terdapat 3 hal penting yang harus dipenuhi dalam perencanaan program munadharah 'ilmiyah. Pertama, model interactive approach. Kedua, dalam ruang lingkup program ini terdapat 3 dimensi. Ketiga, proses perencanaan program ini melalui tahapan-tahapan yang sistematis. 2) Pelaksanaan, terdapat 3 hal penting yang terdapat dalam penyusunan program Munadharah 'ilmiyah. Pertama, tahap pemula, kedua, tahap pelaksanaan program, ketiga, tahap penilaian setelah diadakannya program munadharah 'ilmiyah. 3) Evaluasi terdapat 2 hal penting yang harus dipenuhi dalam evaluasi program munadharah 'ilmiyah, yaitu evaluasi monitoring dan evaluasi komprehensif.
\end{abstract}

Kata Kunci: Evaluasi, Munadharah Ilmiyah, Manajemen Program 


\section{PENDAHULUAN}

Salah satu fenomena kehidupan modern yaitu hadirnya berbagai organisasi dalam kehidupan masyarakat untuk membantu dan mempermudah pemenuhan kebutuhan hidup manusia baik secara individu maupun kelompok (Wijaya and Muhammad Rifa'i 2016), Dalam dunia pendidikanpun dibentuk berbagai macam oraganisasi-organisasi maupun program-program yang tidak lain bertujuan untuk meningkatkan kualitas pendidikan tersebut. Maka untuk membantu merealisasikan tujuan tersebut, sebuah organisasi harus memiliki manajemen yang baik. Hal ini sejalan dengan pendapat (Hakim and Mukhtar, 2018) yang mengatakan bahwa setiap organisasi termasuk organisasi pendidikan akan sangat memerlukan manajemen untuk mengelola kerjasama yang terjadi agar dapat mencapai tujuan.

Secara umum, manajemen adalah suatu proses pengaturan dan pemanfaatan sumberdaya yang ada dalam organisasi melalui kerjasama sumber daya tersebut untuk mencapai tujuan organisasi yang telah ditetapkan secara efektif dan efisien (Wijaya and Rifa'i, 2016). Definisi tersebut sejalan dengan pendapat (Sulastri, 2014)yang mendefinisikan manajemen dengan terperinci yaitu suatu seni mengatur yang meliputi proses, cara, tidakan tertentu seperti perencanaan, pengorganisasian, pengarahan dan pengendalian atau pengawasan yang dilakukan untuk mencapai tujuan tertentu secara efektif dan efisien dengan dan melalui orang lain. Maka manajemen yang baik akan memberikan pandangan bagaimana langkah-langkah dan apa yang harus dilakukan untuk mencapai tujuan pendidikan yang sudah ditetapkan.

Adapun program merupakan serangkaian aktivitas atau kegiatan yang akan dilaksanakan oleh seseorang atau sekelompok orang. (Ananda,2017) menjelaskan bahwa program adalah suatu rencana yang melibatkan berbagai unit yang berisi kebijakan dan rangkaian kegiatan yang harus dilakukan dalam kurun waktu tertentu. Kemudian dalam dunia pendidikan, program sangatlah membantu dalam meningkatkan kualitas pembelajaran. Meskipun program tidak termasuk dalam pendidikan formal, akan tetapi program dapat berperan sebagai pendidikan nonformal. Jika program tersebut dirangkai dengan manajemen yang baik dan jelas, maka tujuan pembelajaran atau program itu sendiri akan mudah terealisasikan. 
Manejemen Program Perencanaan Pelaksanaan dan Evaluasi Munadharah Ilmiyah Pekan 'Arabi Universitas Negeri Malang di Masa Pandemi

Mengingat bahwa Indonesia merupakan negara yang penduduknya mayoritas muslim, maka bahasa asingpun terutama bahasa Arab menjadi perhatian bahkan menjadi kebutuhan pokok bagi penduduk. Sebagian besar instansi-istansi pendidikan menjadikan bahasa Arab sebagai satu program studi atau mata pelajaran wajib (Zainuri, 2019). Bahkan tidak sedikit dari instansi pendidikan tersebut merancang program-program untuk mengembangkan pembelajaran bahasa Arab di instansi masing-masing. Adanya program-program bahasa Arab ini menunjukkan bahwa terdapat inovasi-inovasi baru yang dikembangkan oleh para pecinta bahasa Arab yang tidak lain betujuan untuk membumikan bahasa Arab itu sendiri. Hal ini tentunya menjadi modal besar untuk bisa mengembangkan ataupun menyebarkan luaskan bahasa Arab khususnya di Indonesia.

Salah satu program bahasa Arab bergengsi yaitu program Pekan Arabi yang diselenggarakan oleh Himpunan Mahasiswa Jurusan (HMJ) Sastra Arab Fakultas Sastra Universitas Negeri Malang. Kegiatan atau acara ini diperuntukkan untuk tingkat siswa SMA/MA sederajat dan tingkat Universitas (mahasiswa/i aktif S1) se-Indonesia. Adapun tujuan diadakannya program ini yaitu untuk mewujudkan sarana berbagi dan bertukar ilmu pengetahuan serta untuk menambah wawasan seputar bahasa, khususnya bahasa Arab bagi para pecinta bahasa Arab di Indonesia baik itu pembelajar, pengajar, dan pakar. Disamping itu, kegiatan ini dapat berfungsi sebagai media evaluasi dalam meningkatkan kualitas pengajaran bahasa Arab di Indonesia.

Ada banyak perlombaan yang diadakan dalam program Pekan Arabi ini, diantaranya yaitu debat (munadharah 'ilmiyah). Debat merupakan kegiatan menyampaikan dan mempertahankan pendapat (argumen). Meskipun debat sering kali disalahartikan dan disebut sebagai kegiatan berkeras kepala dan tidak mau kalah, namun pada dasarnya debat adalah prosen menyusun argumen dari pernyataan yang masuk akal untuk meyakinkan lawan bicaranya agar dapat menerima pendapat argumen yang dilontarkan (Pratama, Hendi, 2018). Di mana dengan diadakannya perlombaan ini dapat meningkatkan kemampuan peserta sehingga mampu menyampaikan dan mempertahankan pendapat tentunya dengan menggunakan bahasa Arab. 
Seiring dalam penulisan kajian ini, peneliti menemukan beberapa studi pendahuluan, diantaranya yaitu (Fatim et al., 2020) meneliti tentang manajemen perencanaan program festival Jazirah Arab yang merupakan program rutin diselenggarakan oleh Jurusan Bahasa dan Sastra Arab Universitas Negeri Malang. Adapun kesimpulan dari penelitian ini yaitu proses perencanaan program sudah optimal dan sudah sesuai dengan standar yang ada. Kemudian (Roviin, 2020) meneliti tentang manajemen program kursus intensif bahasa Arab. Kesimpulan dari program ini yaitu program tersebut berjalan secara baik karena telah memenuhi fungsi dari manajemen. (Nurcholis, 2007) meneliti tentang kontekstualisasi manajemen program intensive course bahasa Arab di IAIN Tulungagung yang menyimpulkan bahwa pelaksanaan program tersebut masih kurang baik disebabkan oleh tidak sejalannya koordinasi antara komponen program dalam kampus.

Kemudian perbedaan antara penelitian ini dan Studi pendahuluan di atas antara lain yaitu Studi pendahuluan yang dilakukan Fatim, et al hanya berfokus pada perencanaan sebuah program sedangkan penelitian ini akan membahasa perencanaan, pelaksanaan dan evaluasi program. Adapun Studi pendahuluan yang dilakukakan Roviin meneliti tentang program kursus intensif sedangkan penelitian ini meneliti program debat bahasa. Selanjutnya Studi pendahuluan yang dilakukakan Nurcholis fokus meneliti pelaksanaan program intensive course bahasa Arab sedangkan penelitian ini meneliti perencanaan, pelaksanaan dan evaluasi program debat bahasa.

Walaupun kajian ini sudah banyak yang menelitinya, namun ada beberapa hal mendasar yang luput dari analisa, yaitu tentang manajemen program di masa pandemi atau program daring (dalam jaringan). Hal ini berkaitan dengan kebijakan pemerintah yang menetapkan bahwa segala aktivitas termasuk aktivitas pendidikan harus dilakukan secara online. Oleh karena itu, fokus penelitian ini tentang manajemen program munadharah 'ilmiyah Pekan Arabi di Universitas Negeri Malang sebagai strategi untuk meningkatkan kemampuan bahasa Arab.

Berdasarkan pemaparan di atas, secara umum penelitian ini bertujuan untuk medeskripsikan manajemen program munadharah 'ilmiyah pekan Arabi di Universitas Negeri Malang. Adapun tujuan secara khusus terperinci sebagai berikut: 1) mendeskripsikan manajemen perencanaan program munadharah 
Manejemen Program Perencanaan Pelaksanaan dan Evaluasi Munadharah Ilmiyah Pekan 'Arabi Universitas Negeri Malang di Masa Pandemi

'ilmiyah Pekan Arabi di Universitas Negeri Malang, 2) mendeskripsikan manajemen pelaksanaan program munadharah 'ilmiyah Pekan Arabi di Universitas Negeri Malang, dan 3) mendeskripsikan manajemen evaluasi program munadharah 'ilmiyah Pekan Arabi di Universitas Negeri Malang.

\section{TEORI}

Manajemen ialah proses mendapatkan kegiatan lewat usaha orang lain. Bisa dimengerti manajemen yaitu kekuatan utama dalam organisasi yang mengkoordinir bermacam aktivitas bagian- bagian dan juga berhubungan dengan area. Sehingga manajemen suatu proses memadukan sumber energi yang tidak berhubungan ke dalam totalitas sistem buat pencapaian tujuan. Manajemen berupaya memfokuskan atensi atas proses pokok administrasi mencakup perencanaan, pelaksaanaan serta penilaian. Kegiatan manajerial berlangsung pada organisasi, pembelajaran, sosial serta organisasi lain di mana faktor manusia serta sumber energi raga dipadukan buat menggapai tujuan organisasi. Manajemen mempunyai unsur- unsur yang meliputi: Faktor manusia (manajer serta anggotanya). Manajemen merupakan proses yang dilaksanakan oleh manajer supaya organisasi berjalan mengarah pencapaian tujuan cocok efisien serta efesien (Syafruddin, 2005, h.70).

Dari pendapat di atas, dapat disimpulkan bahwa manajemen program adalah kegiatan yang dimulai dari perencanaan, pelaksaanaan dan evaluasi agar mencapai tujuan yang sudah ditetapkan secara efektif dan efisien. Adapun fungsifungsi manajemen tersebut diantaranya sebagai berikut:

\section{Manajemen Perencanaan Program}

Perencanaan merupakan fungsi utama manajemen dalam sebuah program ataupun organisasi. Perencanaan dalam organisasi bersifat esensial, karena pada kenyataannya fungsi perencanaan memegang peran lebih dibandingkan fungsifungsi yang lain dan pada dasarnya fungsi-fungsi manajemen yang lain merupakan pelaksanaan atas keputusan-keputusan perencana (Indartono, 2013). Hal ini didukung dengan pendapat (Indartono, 2013) yang menyatakan bahwa perencanaan merupakan proses terpenting dari semua fungsi manajemen karena tanpa perencanaan, fungsi-fungsi lainnya tak dapat berjalan. Oleh karena itu, seorang perencana seyogyanya mengerahkan seluruh kemampuannya untuk 
menyusun perencanaan yang baik dan jelas sehingga fungsi-fungsi manajemen yang lain dapat terlaksana sebagaimana mestinya.

Dalam menyusun perencanaan, setidaknya terdapat empat model yang digunakan, yaitu: bottom up approach, rencana kegiatan disusun dan diusulkan oleh pihak bawah kepada pihak atas; top down approach, rencana kegiatan disusun dan ditetapkan oleh pihak atas kemudian direalisasikan oleh pihak bawah; interactive approach, rencana kegiatan disusun dan direalisasikan bersama-sama oleh pihak atas dan pihak bawah; dual-level approach, rencana kegiatan disusun oleh masing-masing pihak atas atau bawah kemudian dilakukan penyelarasan (Sugiyanto, 2008). Kemudian dalam perencanaan juga terdapat tiga dimensi yang saling berinteraksi satu sama lain, yaitu: dimensi waktu yang meliputi jangka pendek (minimal 1 tahun), jangka menengah (1-4 tahun), dan jangka panjang (4-8 tahun), dimensi spasial berkaitan dengan ruang dan batasan wilayah yang meliputi nasional, regional dan tata ruang, dan dimensi tingkatan teknis perencanaan yang meliputi perencanaan makro, mikro, sektoral, kawasan, dan proyek (Usman, 2008).

Adapun tahapan-tahapan yang harus dilalui dalam menjalankan proses perencanaan antara lain: a) melakukan prakiran, b) menetapkan tujuan, c) menyusun program, d) melakukan penjadwalan terhadap kegiatan-kegiatan dalam program, e) menyusun anggaran yang dibutuhkan, f) mengembangkan prosedur pelaksanaan program, g) menetapkan interprestasi kebijakan program (Syafruddin, 2005). Dengan dilakukannya tahapan-tahapan tersebut, maka dapat dipastikan perencanaan yang disiapkan akan tersusun sistematis sehingga pelaksanaan program akan lebih terarah.

\section{Manajemen Pelaksanaan Program}

Pelaksanaan merupakan suatu tindakan untuk mengusahakan agar semua anggota kelompok berusaha untuk mencapai sasaran uang sesuai dengan perencanaan manajerial dan usaha-usaha organisasi. Dengan kata lain pelaksanaan adalah proses implementasi dari segala bentuk rencana, konsep, ide, dan gagasan yang telah sebelumnya disusun, baik pada level manajerial maupun level operasional dalam rangka mencapai tujuan, yaitu visi dan misi organisasi. Dalam menjalankan rencana yang sudah sebelumnya disusun sedemikian rupa terkadang dalam implementasi bisa jadi terdapat berbagai macam kemungkinan- 
Manejemen Program Perencanaan Pelaksanaan dan Evaluasi Munadharah Ilmiyah Pekan 'Arabi Universitas Negeri Malang di Masa Pandemi

kemungkinan yang tidak sesuai dengan yang diharapkan atau bahkan berhasil sukses sebagaimana yang dicita-citakan. Berbagai macam kemungkinan itu kemudian terengkum dalam (Aditama, 2020, h.16).

Program menurut (Republik Indonesia, 2004) menjelaskan bahwasannya program merupakan suatu kegiatan yang dilaksanakan oleh instansi pemerintah atau lembaga untuk mencapai tujuan atau suatu kegiatan yang dilaksanakan oleh instansi masyarakat. Maka dapat disimpulkan, program pelaksanaan adalah proses implementasi yang telah disusun rencana dengan baik yang dilaksanakan oleh suatu instansi untuk mencapai tujuan yang diinginkan.

Unsur dari pelaksanaan ialah berupa tindakan komando, tindakan dari pembimbingan, memberikan petunjuk serta arahan yang menuju pada tujuan. Dapat dikatakan bahwasannya pelaksanaan merupakan usaha, cara, teknik serta metode dari sebuah keanggotaan organisasi untuk mencapai tujuan secara efektif, efisiensi dan ekonomis (Sule and Kurniawan Saefullah, 2010, h.8).

Fungsi dari pelaksanaan yaitu memberikan tujuan secara kontinu dari perencaan yang telah dibuat, membudayakan prosedur standar, menghindari dengan adanya kemungkinan-kemungkinan yang terjadi, membina anggota dengan displin dari segi kualitas dan kuantitas, serta membina motivasi secara terarah (Siswanto, 2006, h.112-113). Program pelaksanaan dapat berjalan dengan baik dan lancar dengan diperhatikannya kepemimpinan, motivasi dan komunikasi (Badrudin, 2015, h.152).

\section{Manajemen Evaluasi Program}

Penilaian program merupakan sesuatu proses ataupun aktivitas ilmiah yang dicoba secara berkepanjangan serta merata bagaikan upaya pengendalian, penjaminan serta penetapan kualitas (nilai serta makna) sesuatu program, bersumber pada kriteria serta pertimbangan tertentu untuk membuat sesuatu keputusan serta pertanggungjawaban dalam melakukan program. Dalam aktivitas penilaian langkah awal yang wajib dicermati merupakan tujuan penilaian. Penentuan tujuan sangat tergantung dengan tipe penilaian yang digunakan, tujuan penilaian program merupakan untuk mengenali keefektifan serta efesiensi penerapan sesuatu program, untuk mengenali ketercapaian tujuan yang sudah diresmikan, untuk mengenali relevansi penerapan program dengan terencana program, untuk mengenali akibat apa yang ditimbulkan sehabis program 
dilaksanakan, untuk mengenali kekuatan serta kelemahan program, serta sediakan data untuk membuat keputusan. Penilaian program terdiri atas sebagian tipe, serta tiap tipe penilaian program itu memiliki tujuan tertentu, semacam penilaian kebutuhan dan kelayakan, penilaian perencanaan serta pengembangan, penilaian monitoring, penilaian efisiensi-ekonomis, penilaian akibat, serta penilaian program komprehensif. Ada pula guna penilaian program secara spesial merupakan menolong para pengembang program dalam upaya membetulkan serta menyempurnakan penerapan program, baik sebagian- sebagian( komponenkomponen tertentu) ataupun secara totalitas (Arifin, 2019, h.11).

Penilaian program ialah aktivitas yang sistematis dalam rangka mencari data tentang hasil kinerja serta kriteria yang jadi standar yang sudah diresmikan tadinya guna menanggulangi masalah- masalah, maupun hambatan dalam penerapan program. Dalam penilaian program tidak lumayan cuma memandang serta difokuskan dari aspek penilainnya saja, namun terdapat banyak aspek yang bisa dilihat buat mengukur sukses ataupun tidaknya sesuatu program. Dengan terdapatnya penilaian terhadap program yang terdapat hingga hendak dikenal kelemahan- kelemahan yang ada didalamnya sehingga bisa dilengkapi kelemahan tersebut, ataukah ada kendala- kendala dalam proses penerapannya sehingga bisa diberikan pemecahan, ataukah ada kesenjangan antara penerapan dengan tujuan program sehingga dicari pangkal perkaranya serta dipecahkan. Tujuannya supaya program yang telah terdapat tadinya bisa berjalan efisien serta hasilnya bisa diukur sepanjang mana efektifitasnya dalam proses penerapannya (purwanto and Suparman, 1999).

Menurut Arikunto dan Jabar bahwasannya penilaian program mempunyai sebagian ciri yang kesemuanya berhubungan satu serta yang lain. Diantarnya: a) Terdapatnya indikator- indikator yang jadi penentu terhadap keberhasilan program bagaikan objek berarti yang wajib dikaji serta dianalisis secara mendalam, b) Dalam penerapan penilaian kaidah- kaidah riset ialah pijakan dalam melaksanakan penilaian. Bukan penilaian yang didasarkan atas kehendak sendiri, c) proses penilaian program ialah aktivitas yang sistematis serta terkonsep sehingga penerapannya wajib dirancang sedemikian rupa cocok dengan urutannya tiap- tiap bukan dengan yang termudah yang bersumber pada kemauan penerapan penilaian, d) Penerapan penilaian program ialah aktivitas penilaian yang diawali 
Manejemen Program Perencanaan Pelaksanaan dan Evaluasi Munadharah Ilmiyah Pekan 'Arabi Universitas Negeri Malang di Masa Pandemi

dari identifikasi komponen- komponen program sampai sub komponen program supaya hasil penilaian sanggup menggambarkan secara rinci ataupun perinci keadaan nyata dari program yang terlaksana (Arikunto \& Jabar, 2009).

\section{Program Kebahasaan Online}

Pada abad ke 21, perkembangan dan kemajuan teknologi informasi dan komunikasi berkembang pesat sehingga pengaruh teknologi berdampak pada aspek kehidupan, termasuk pada aspek pendidikan. Banyak cara untuk memanfaatkan TIK (teknologi informasi dan teknologi) di era global ini sangat yang memberikan akses dengan alternatif serta mengoptimalkan pemanfaataan sumber-sumber pembelajaran yang ada (Belawati, 2019, h.3). Sejarah menyebutkan, pada pertengahan abad ke 18, sistem pembelajaran jarak jauh sudah ada dan pelaksanaan pembelajarannya menggunakan teknologi yang sederhana. Oleh karena itu, dapat dikatakan bahwasannya pembelajaran online merupakan pembelajaran dengan menggunakan jaringan internet. Dalam istilah bahasa Indonesia, diterjemahkan sebagai 'pembelajaran dalam jaringan' atau 'pembelajaran daring' (Belawati, 2019, h.6).

Program menurut KBBI online, program adalah suatu rancangan tentang asas dan usaha mengenai ketatanegaraan, perekonomian dan lain sebagainya. Sedangkan, menurut Chaer Bahasa merupakan alat ucap manusia yang digunakan oleh sekelompok anggota masyarakat sebagai interaksi dengan orang lain dan sebagai mengidentifikasi diri (2003 h.30).

Dari pemaparan diatas, maka dapat disimpulkan program kebahasaan online ialah rancangan kegiatan atau aktivitas berkaitan tentang kebahasaan yang disusun dan dilaksanakan dalam sistem jarak jauh atau daring (dalam jaringan).

\section{Munadharah 'Ilmiyah}

Pembelajaran bahasa Arab tidak hanya berbentuk formal yang biasanya diadakan di dalam kelas, akan tetapi bisa diaplikasikan pada pembelajaran non formal. Hal ini diterapkan dalam program pekan Arabi, yang diselenggarakan melalui lomba yang berkaitan dengan pembelajaran bahasa Arab, seperti khatabah, video inovasi pembelajaran, qira'atus syi'ri, munadharah 'ilmiyah, taqdim al-Qishah, olimpiade bahasa Arab, di Universitas Negeri Malang yang bertujuan untuk mengembangkan pembelajaran bahasa dan seni Arab pada mahasiswa 
jurusan bahasa Arab di Indonesia. Pengembangan pembelajaran bahasa Arab dan seni Arab ini, dilakukan untuk menjadikan mahasiswa-mahasiswa agar dapat meningkatkan produktivitas pembelajaran bahasa Arab dengan mengapresiasikan talenta-talenta mereka, serta dapat mengetahui lebih banyak bahwa bahasa dan seni Arab merupakan akar sejarah yang memiliki unsur keindahan di dalamnya. Program debat bahasa Arab ini diadakan setiap tahunnya, tepatnya pada tahun ajaran semester ganjil. Meski program debat bahasa Arab universitas luar negeri dari Malaysia yang juga ikut berpartisipasi dalam program debat bahasa Arab ini.

Dengan adanya peserta dari universitas internasional ini, menjadikan program debat bahasa Arab ini sudah mulai dikenal dan diminati oleh mahasiswa universitas-universitas nasional maupun internasional. Berkembangnya suatu program debat bahasa Arab ini, tentunya terdapat tujuan-tujuan yang dioprasionalkan dengan berbagai kegiatan agar misi dapat tercapai. Program yang baik, yaitu program yang telah didasari oleh model teoritis secara jelas, seperti menentukan persoalan yang ingin diatasi keterhambatannya, apabila telah menentukan arah, tujuan, visi, misi dan kegiatan apa saja, bahkan sampai pada proses evaluasi apa yang akan dilakukan (Fatim et al., 2020, h.39).

\section{METODE}

Metode Dalam sub metode penelitian, peneliti memaparkan jenis penelitian, sumber data, teknik pengumpulan data, dan teknik analisis data, yaitu sebagai berikut:

\section{Jenis penelitian}

Jenis penelitian dalam penelitian ialah jenis penelitian kualitatif metode deskriptif. Penelitian ini mengetahui gejala-gejala dari proses perencanaa, pelaksanaan dan evaluasi dalam program munadharah 'ilmiyah pekan Arabi di masa pandemi. Sejalan dengan Creswell, jenis penelitian ini, peneliti bergantung terhadap informasi dari partisipan atau objek, yaitu berupa pertanyaan bersifat umum, dengan pengumpulan data berupa teks atau kata-kata dari partisipan, kemudian menganalisis data berupa teks dan melakukan penelitian secara subyektif (2008, h.46).

\section{Sumber data}

Penelitian ini menggunakan dua sumber utama, yaitu: 
a. Sumber data primer, merupakan sumber data utama yang ditemukan secara langsung oleh peneliti (Thoifah, 2015, h.38). Sumber data yang digunakan ialah hasil dari wawancara dari ketua pelaksana program pekan Arabi dan ketua koordinasi acara pekan Arabi di Universitas Negeri Malang.

b. Sumber data sekunder, merupakan sumber data untuk penguat dari sumber data primer, data ini ditemukan secara tidak langsung dari lapangan, biasanya berupa data yang sudah diterbitkan oleh pihak lain (Thoifah, 2015, h.38). Peneliti menggunakan berupa hasil dari dokumentasi petunjuk teknis dan laporan pertanggungjawab.

Dalam penelitian ini, peneliti menggunakan metode wawancara dan dokumentasi. Dalam metode wawancara, peneliti melakukan wawancara kepada: a) ketua pelaksana program pekan Arabi, peneliti mengajukan pertanyaan tentang bagaimana dan apa persiapan yang dilakukan oleh panitia sebelum lomba diadakan di masa pandemi b) ketua koordinasi acara pekan Arabi, peneliti mengajukan pertanyaan tentang bagaimana pra acara, langkah-langkah persiapan, alur perlombaan kepada seluruh peserta serta kendala terhadap perlombaan debat Arabi. Dalam metode dokumentasi, peneliti menggunakan dokumentasi berupa buku panduan lomba pekan Arabi serta laporan pertanggungjawaban di masa pandemi oleh ketua pelaksana.

\section{Teknik analisis data}

Teknik analisis data, peneliti menggunakan teori Miles dan Huberman (Miles, Huberman and Saladana, 2014, h.22). Langkah-langkah analisis data, meliputi: pertama, peneliti mengumpulkan data dari hasil wawancara dari ketua pelaksana program pekan Arabi dan ketua koordinasi acara, serta dokumentasi yang terdapat dalam buku panduan program pekan Arabi dan laporan pertanggungjawaban; kedua, reduksi data yang dilakukan oleh peneliti yaitu memilih dan memilah dari hasil wawancara dan dokumentasi yang diperlukan dalam perlombaan munadharah 'ilmiyah ; ketiga, display data, yaitu peneliti mengolah data yang telah diklasifikasikan berdasarkan pola pendekatan perencanaan, 
pelaksanaan, dan evaluasi terhadap lomba munadharah 'ilmiyah; keempat, conclusion drawing yaitu peneliti menyimpulkan dari hasil penyajian data.

\section{HASIL DAN PEMBAHASAN}

Hasil dan Pembahasan manajemen perencanaan program munadharah 'ilmiyah Pekan Arabi telah dilakukan peneliti sesuai dengan apa yang menjadi fokus dari penelitian ini. Pertama, perencanaan yang dilakukan oleh panitia yaitu menetukan model perencanaan, hal ini sesuai dengan apa yang diungkap Sugiyanto, bahwa dalam membentuk dan menyusun sebuah perencanaan, perencana harus memilih model pendekatan yang menjadi tolak ukur keberhasilan menjalankan proses perencanaan. Adapun dalam program ini, model yang digunakan dalam menyusun perencanaan yaitu model interactive approach, dimana dalam model ini rencana kegiatan disusun dan direalisasikan bersamasama oleh pihak atas dan pihak bawah (Sugiyanto, 2008, h.31). Dengan model ini, maka desain acara di program ini akan seimbang atau tidak berat sebelah karena terdapat interaksi langsung antara ketua Jurusan sebagai pihak atas dan HMJ sebagai pihak bawah.

Kemudian kedua, ruang lingkup perencanaan munadharah 'ilmiyah dalam program Pekan Arabi ini dipengaruhi oleh tiga dimensi yang saling berkaitan satu sama lain. Dalam dimensi waktu, program munadharah 'ilmiyah bahasa Arab Pekan Arabi tergolong dalam perencanaan jangka pendek karena program ini merupakan program rutin yang diselenggarakan selama satu tahun sekali. Adapun dalam dimensi spasial, program ini tergolong dalam perencanaan nasional karena memang diperuntukkan untuk tingkat siswa SMA/MA sederajat dan tingkat Universitas (mahasiswa/i aktif S1) se-Indonesia. Kemudian dalam dimensi teknis perencanaan, program ini tergolong dalam perencanaan proyek karena pelaksanan program ini memiliki waktu dan tempat yang terbatas. Hal ini menunjukkan bahwa ruang lingkup perencanaan program ini sudah baik dan jelas, karena sesuai dengan pendapat Usman, (2008, h.81) yang mengatakan bahwa dalam ruang lingkup sebuah perencanaan harus terdiri dari tiga dimensi yang berkaitan satu sama lain.

Ketiga, dalam proses perencanaan munadharah 'ilmiyah dalam program Pekan Arabi ini sudah melalui tahapan-tahapan seperti yang sudah dijelaskan 
Manejemen Program Perencanaan Pelaksanaan dan Evaluasi Munadharah Ilmiyah Pekan 'Arabi Universitas Negeri Malang di Masa Pandemi

dalam hasil penelitian di atas. Hal tersebut menunjukkan proses perencanaan sudah disusun dengan baik dan sistematis. Tahapan-tahapan yang dilalui dalam proses perencanaan program ini sesuai dengan pendapat (Syafruddin, 2005, h.72) yang mengatakan bahwa tahapan perencanan antara lain: melakukan prakiraan, menentukan dan menetapkan tujuan, menyusun program, melakukan penjadwalan terhadap kegiatan-kegiatan dalam program, menyusun anggaran yang dibutuhkan, mengembangkan prosedur pelaksanaan program, menetapkan interprestasi kebijakan program.

Berdasarkan pembahasan di atas, terdapat 3 hal penting yang harus dipenuhi dalam perencanaan program munadharah 'ilmiyah. Pertama, model yang digunakan dalam penyusunan desain program ini adalah model interactive approach. Kedua, dalam ruang lingkup program ini terdapat 3 dimensi, antara lain: dimensi waktu yang tergolong perencanaan jangka panjang, dimensi spasial yang tergolong tingkat nasional, dan dimensi teknis yang tergolong perencanaan proyek. Ketiga, proses perencanaan program ini melalui tahapan-tahapan yang sistematis, dalam artian sudah berjalan sesuai dengan mengikuti prosedur yang ada.

\section{Pelaksanaan}

Unsur dari pelaksanaan, seperti yang telah dijelaskan sebelumnya meliputi tindakan komando, tindakan dari pembimbingan, memberikan petunjuk serta arahan yang menuju pada tujuan (Sule and Kurniawan Saefullah, 2010, h.8). Namun dalam program munadharah 'ilmiyah unsur pelaksanaan meliputi tindakan dari pembimbingan yaitu adanya Koordinator Munadharah 'Ilmiyah yang bertanggung jawab atas acara debat, serta adanya juri yang menjadi tim penilaian dari semua anggota Munadharah 'Ilmiyah.

Adapun petunjuk serta arahan dalam program Munadharah 'Ilmiyah yaitu meliputi susunan acara yang telah terlampirkan dimulai dari acara pembukaan pada hari Minggu, 25 Oktober serta dilanjutkan dengan lomba-lomba setelahnya sampai 1 bulan penuh, jadwal live perform, serta adanya teknis dalam perlombaan. Perlombaan ini menggunakan sistem Asian Parliamentary Debate, sistem penilainnya menggunakan sistem scoring atau poin tertinggi setiap babaknya, setiap tim terdapat 3 anggota peserta. 
Fungsi dari pelaksanaan menurut (Siswanto, 2006, h.112-13), yaitu menghindari adanya kemungkinan-kemungkinan, dalam program Munadharah 'Ilmiyah memiliki peraturan dalam lomba meliputi kuota Munadharah 'Ilmiyah maksimal 24 tim, lomba dimulai 30 menit sebelum acara tiba, semua tim berada di room meeting secara daring sebelum waktu ditentukan, tidak adanya alasan untuk anggota tim yang tidak bisa hadir kecuali alasan yang mendesal, seperti sakit dan keluarga yang meninggal, tidak adanya izin kepada panitia maka tim didiskualisifikasi, tidak diperkenankan untuk semua tim meninggalkan room meetimg.

Menurut Badruddin, pelaksanaan program dapat berjalan dengan baik dan lancar, yaitu adanya kepemimpinan, motivasi dan komunikasi (2015, h.152). Dalam hal ini, 1) kepemimpinan Munadharah 'Ilmiyah meliputi susunan panitia yang terlampirkan pekan Arabi dari Himpunan Mahasiswa Jurusan Sastra Arab Univesitas Negeri Malang, meliputi Pelindung (Dekan Fakultas Sasta, Wakil Dekan III Fakultas Sastra, Ketua Jurusan Sastra Arab), Pembimbing (Pembina HMJ), Penanggung Jawab (Ketua HMJ Sastra Arab), Panitia Pelaksana (Ketua, Sekretaris, Bendahara, Sie. Acara, Sie Kesekretariatan, Sie. Pubekdok, Sie. Art Design, Sie. LO, Koordinator Munadharah 'Ilmiyah. 2) motivasi, ditunjukkan dengan adanya pemenang dari perlombaan ini, dengan kategori juara 1, 2, dan 3 serta Best Speaker tingkat universitas (mahasiswa/i aktif s1). 3) komunikasi, perlombaan ini menggunakan sistem daring, oleh karena itu sistem daring dengan menggunakan aplikasi WhatsApp Group untuk mengkoordinir juri, panitia serta anggota peserta. Untuk pelaksanaan lombanya antara juri dan anggota peserta dan panitia sebagai penanggung jawan, menggunakan aplikasi zoom.

\section{Evaluasi}

Sebagaimana dikenal kalau penilaian program terdiri atas sebagian tipe, serta tiap tipe penilaian program itu memiliki tujuan tertentu, semacam penilaian kebutuhan dan kelayakan, penilaian perencanaan serta pengembangan, penilaian monitoring, penilaian efisiensi-ekonomis, penilaian akibat, serta penilaian program komprehensif. Ada pula guna penilaian program secara spesial merupakan menolong para pengembang program dalam upaya membetulkan serta menyempurnakan penerapan program, baik sebagian- sebagian( komponenkomponen tertentu) ataupun secara totalitas (Arifin, 2019, h.10). 
Manejemen Program Perencanaan Pelaksanaan dan Evaluasi Munadharah Ilmiyah Pekan 'Arabi Universitas Negeri Malang di Masa Pandemi

Adapun evaluasi program manajemen bahasa Arab dalam munadharah 'ilmiyah pekan Arabi di Universitas Negeri Malang menggunakan evaluasi monitoring dan komprehensif, evaluasi monitoring dimaksudkan untuk memantau apakah program berjalan dan berfungsi secara efektif dan apakah program terlaksana sebagaimana semestinya. Adapun evaluasi komprehensif adalah untuk menilai program secara menyeluruh meliputi evaluasi perencanaan program, pelaksanaan program monitoring dan efisien, dan evaluasi dampak program. Evaluasi program manajemen bahasa Arab dalam munadharah 'ilmiyah pekan Arabi di Universitas Negeri Malang telah terencana dengan baik. Dikarenakan ketika munadharah 'ilmiyah dilaksanakan, dengan memiliki beberapa kriteria penilaian, yaitu, materi, teamwork, manner dan bahasa. melihat setelah diadakannya program munadharah 'ilmiyah berlangsung, yaitu adanya beberapa kendala seperti keterlambatan kegiatan berlangsung, keterlambatan oleh panitia, dan adanya juri yang tidak hadir. Berdasarkan pembahasan di atas, terdapat evaluasi monitoring dan evaluasi komprehensif dalam program munadharah 'ilmiyah Pekan Arabi ini.

\section{SIMPULAN}

Simpulan Dari hasil penelitian dan pembahasan diatas dapat disimpulkan bahwasanya program manajemen munadharah 'ilmiyah pekan Arabi di universitas negeri malang yang terdiri perencanaan, pelaksanaan, dan evaluasi di masa pandemi, 1) Perencanaan, terdapat 3 hal dalam perencanaan program munadharah 'ilmiyah. Pertama, model yang digunakan adalah model interactive approach. Kedua, dalam ruang lingkup program ini terdapat 3 dimensi, antara lain: dimensi waktu, dimensi spasial yang dan dimensi teknis yang Ketiga, proses perencanaan program ini melalui tahapan-tahapan yang sistematis, artinya telah mengikuti prosedur yang ada.

Sedangkan 2) Pelaksanaan, terdapat 3 hal dalam penyusunan program Munadharah 'ilmiyah. Pertama, tahap pemula Kedua, tahap pelaksanaan Ketiga, tahap penilaian. Kemudian 3) Evaluasi terdapat 2 hal penting yang harus dipenuhi dalam evaluasi program munadharah 'ilmiyah, yaitu evaluasi monitoring dan evaluasi komprehensif. 


\section{DAFTAR PUSTAKA}

Aditama, A. R. (2020) Pengantar Manajemen Teori dan Aplikasi. Malang: Perdana Publishing.

Ananda, R. and T. R. (2017) Pengantar Evaluasi Program Pendidikan. Edited by C. Wijaya. Perdana Publishing.

Arifin, Z. (2019) Evaluasi Program. Bandung: Remaja Rosdakarya.

Arikunto, S. and Jabar, C. S. A. (2009) Evaluasi Program Pendidikan Pedoman Teoretis Praktis Bagi Mahasiswa dan Praktisi Pendidikan. Jakarta: Bumi Aksara.

Badrudin (2015) Dasar-Dasar Manajemen. Bandung: Alfabeta.

Belawati, T. (2019) Pembelajaran Online. Cetakan Pe. Banten: Universitas Terbuka.

Chaer, A. (2003) Linguistik Umum. Jakarta: Rineka Cipta.

Creswell, J. W. (2008) Education Research Planning, Conducting, and Evaluating Quantitative and Qualitative Research. New Jersey: Pearson Prentice Hall.

Fatim, A. L. N. et al. (2020) 'Manajemen Perencanaan Program Festival Jazirah Arab untuk Mengembangkan Bahasa dan Seni Arab', An Nabighoh: Jurnal Pendidikan dan Pembelajaran Bahasa Arab, 22(01), p. 37. doi: 10.32332/an-nabighoh.v22i01.1755.

Hakim, L. and Mukhtar (2018) Dasar-dasar Manajemen Pendidikan. Jambi: Timur Laut Aksara.

Indartono, S. (2013) 'Pengantar Manajemen : Character Inside’, p. 216.

Miles, B. M., Huberman, A. M. and Saladana, J. (2014) Qualitative Data Analysis A Methods Sourcebook. Edition 3. New York: SAGE Publications.

Nurcholis, A. (2007) 'Kontekstualisasi Manajemen Program INTENSIVE COURSE BAHASA ARAB DI IAIN TULUNGAGUNG', pp. 64-78.

Pratama, Hendi, D. (2018) Panduan Debat Kompetitif. Yogyakarta: Erhaka Utama. purwanto and Suparman, A. (1999) Evaluasi Program Diklat. Jakarta: STIALAN.

Republik Indonesia (2004) 'Undang-Undang RI Nomor 25 Tahun 2004 tentang Sistem Perencanaan Pembangunan Nasional', p. 14.

Roviin, R. (2020) 'Manajemen Program Kursus Intensif Bahasa Arab: Studi Pada Metode Mustaqilli', AL-TANZIM: Jurnal Manajemen Pendidikan Islam, 4(2), pp. 118128. doi: 10.33650/al-tanzim.v4i2.1237.

Siswanto, B. (2006) Manajemen Modern. Bandung: Sinar Baru.

Sugiyanto (2008) Dasar-Dasar Manajemen Kristiani. Jakarta: Gunung Mulia.

Sulastri, L. (2014) Manajemen Sebuah Pengantar: Sejarah, Tokoh, Teori, dan Praktik. Bandung: La Goods Publishing.

Sule, E. T. and KurniawanSaefullah (2010) Pengantar Manajemen. Jakarta: Kencana.

Syafruddin, I. N. (2005) Manajemen Pembelajaran. Ciputat: Quantum Teaching.

Thoifah, I. (2015) Statiska Pendidikan dan Metode Penelitian Kuantitatif. Malang: Madani. 
Manejemen Program Perencanaan Pelaksanaan dan Evaluasi Munadharah Ilmiyah Pekan 'Arabi Universitas Negeri Malang di Masa Pandemi

Usman Husaini (2008) Teori Praktik dan Riset Pendidikan. Jakarta: Bumi Aksara.

Wijaya, C. and Muhammad Rifa'i (2016) Dasar-dasar Manajemen: Mengoptimalkan Pengelolaan Organisasi Secara Efektif dan Efisien. Medan: Perdana Publishing.

Wijaya, C. and Rifa'i, M. (2016) 'Dasar Dasar Manajemen: Mengoptimalkan Pengelolaan Organisasi Secara Efektif dan Efesien', p. 15.

Zainuri, M. (2019) 'Perkembangan Bahasa Arab Di Indonesia', Tarling: Journal of Language Education, pp. 231-248. doi: 10.24090/tarling.v2i2.2926. 